\title{
A Longitudinal PRICE COMPARISON FOR MUSIC CDS IN ELECTRONIC AND BRICK-AND-MORTAR MARKETS: PRICING STRATEgIES IN EMERgENT ELECTRONIC COMMERCE
}

\author{
Zoonky Lee \\ University of Nebraska-Lincoln \\ Lincoln, NE \\ Sanjay Gosain \\ University of Maryland \\ College Park, Maryland
}

\begin{abstract}
The Internet has great potential as a medium to reach consumers but we still need to improve our understanding of the impact of IT on information asymmetries governing buyer and seller positions. In this study we are primarily interested in exploring differences in pricing strategies between physical and electronic markets, across product categories and over time, and to understand the reasons for these differences. Choosing a homogenous product - music compact disks, we compare prices, price dispersion and price dynamics on the Internet with brick-and-mortar retailers. We collected price information for 21 currenthits and 23 old-hits albums from top five nationally-known brick-and-mortar $C D$ retailers and nine on-line stores, and repeated the data collection one year later. Overall, 905 data points, 572 from the Internet and 333 from brick-andmortar retail shops were collected. We find that: 1) The Internet market continues to show price dispersion despite the apparently near zero search costs for consumers and the growth of market size; 2) Brick-and-mortar markets execute more consistent and dominant short-term discount strategies for current-hit albums, and as a result, CD prices for old-hit albums are cheaper in the Internet market as was found in other studies, but CD prices for current-hit albums in the physical markets are comparable to prices in the Internet market, and; 3) Price dynamics alter over time with Internet retailers offering cheaper prices for albums and apparently employing more frequent and finer price changes. The results suggest that it is important to look at dynamic price behavior and product portfolio issues when trying to characterize pricing strategy in this media. We propose that IT's role in segmenting customers to extract greater consumer surplus, as well as differences in consumer base and preferences and seller cost structures and differentiation strategies, need to be carefully examined to explain price dispersion and dynamic price behavior.
\end{abstract}




\section{Introduction}

The growing population of Internet users provides a large consumer base for businesses to target. Businesses have responded by increasing their visibility on this medium, and some have tried to move parts of their value chains onto the Internet. Clearly, the Internet has a great potential as a medium to reach consumers. However, our understanding about the Internet as market is still in infancy (Bakos 1998). We need to examine the effectiveness of this medium in effectively disseminating price information to produce efficient markets. We are also interested in investigating how Internet pricing strategy has been set up in a way that is different from the brick-andmortar market. Above all, we are interested in seeing how pricing strategies of sellers in Internet markets will impact market efficiency. Using the music compact disk (CD) market, we empirically test how the expected efficient pricing is borne out in practice and how the pricing strategies of on-line retail shops are different from traditional markets as they adjust to the new environment. Two categories of albums - current hits and old hits based on the expectation that they have distinctive pricing patterns due to differences in volumes, price sensitivity and customer segment appeal are collected at two different points in time, in the expectation that we would observe the dynamic pricing strategies in the two markets. Through this effort we hope to acquire a better understanding of the difference in strategies utilized by conventional stores and on-line sites.

\section{Theoretical Underpinnings}

One theme consistently discussed in the electronic markets literature is that, with the advent of electronic markets, the buyer will be better off in extracting a share of the sellers' profit (Benjamin \& Wigand 1995). It is expected that a reduction of consumer search costs would occur through information technology (Bakos 1997). The hypothesis, therefore, predicts that electronic markets will reduce searching costs resulting in efficiency gains, and also reduce information asymmetries for buyers by helping them to be better informed about prices, leading to price convergence. Neoclassical economic theory suggests that in the absence of transaction costs there should be pure price-based competition for homogeneous goods. The central implication of costly information-gathering is that the equilibrium will not occur at the perfectly competitive price. Economic models (Salop 1979) have argued that positive consumer search costs can lead to prices above marginal cost in equilibrium, even for otherwise homogeneous products. Electronic markets, however, reduce transaction costs resulting in efficiency gains, and also reduce information asymmetries for buyers by helping them be better informed about prices. In competitive market conditions the classical economic model suggests that market price will converge to marginal cost of sellers (i.e. Bertrand model). The Bertrand model, named after a 19th century French economist, is a model of price-taking firms facing perfectly elastic demand curves. Even with just two firms, if the firms 
compete on price, the outcome is the same as perfect competition - thus as search costs converge to zero, price dispersion is expected to diminish. When we compare the electronic marketplace with traditional shopping, the former offers a huge search space coupled with low search and transaction cost. Since, in the electronic market, search costs are typically smaller than the brick-and-mortar market, it is proposed that

Hypothesis 1: Price dispersion on the Internet will be lower than the price dispersion in the brick-and-mortar market.

Improvement in retailer cost structures may also contribute to lower price levels in electronic marketplaces (Smith, Bailey \& Brynjolfsson 1999). Improved cost structures may lead to more efficient pricing as low market entry costs may limit the price premiums sustainable by existing market participants by increasing actual or potential competition (Milgrom \& Roberts 1982). Also, favorable cost structures can lead to lower price levels in the long run by decreasing the underlying costs on which any price premiums are based. Thus it is hypothesized that

\section{Hypothesis 2: Prices in electronic markets will be lower than prices in physical markets.}

Reduced menu costs, the cost related to changing prices, for retailers in electronic markets allow retailers to adjust their prices with ease. Sheshinski and Weiss (1993) describe how menu costs affect the setting of prices and often explain the non-optimal prices in an economy. In electronic markets, price changes are supported through flexible information systems that will significantly reduce the effort required to change prices needed in physical markets. Menu costs are important from the standpoint of buyer welfare and market efficiency because high menu costs can lead to stickiness in prices as retailers will not be able to adjust prices in response to supply or demand changes. In addition to considerations of menu costs, price dynamics is also influenced by changes in the competitive structure of the industry. Bailey (1998), for example proposed that immaturity of the market may be a contributing factor based on the observation that during the 3 months following Barnes and Noble's Internet entry on March 19, 1997, Amazon.com dropped its prices by nearly 10 percent to match the prices charged by their new competitor. Differences in cost structure or business models of industry participants might also lead to differences in pricing over time. For instance, firms may periodically offer price breaks to reduce inventory holding costs or the risk of obsolescence. In non-pure business models, firms may be able to reduce prices to build traffic to generate revenues through advertising or sales through other induced or non-planned purchases. Based on the hypothesized reduction in menu costs and changing competitive structure of electronic markets it is hypothesized that 
Hypothesis 3: The rate of change of prices in electronic markets would be greater than in physical markets.

Market prices are the result of deliberate supply-side pricing strategies of sellers as well as conditions impacting the demand side. While the previous three hypotheses are based on economic analysis of the demand-side factors in electronic commerce, we also expect that sellers will vary their pricing strategies based on the types of products they sell, and these strategies will intervene with demand conditions. In this study, we expect that current-popular and niche products have fundamental differences in their product volumes, price sensitivity and customer segment appeal. We also expect that these differences are recognized by sellers and taken into account in their pricing strategies. Hence, we expect that pricing patterns will be different for the different categories of products.

Hypothesis 1 a: Differences in price dispersion between online and physical markets will depend on the type of products (popular or niche).

Hypothesis 2a: Differences in prices between online and physical markets will depend on the type of products (popular or niche).

Hypothesis 3a: Differences in the rate of change of prices between online and physical markets will depend on the type of products (popular or niche).

\section{Research Direction}

Recent studies have begun to empirically investigate whether prices and price dispersion in electronic markets are lower than prices and price dispersion in physical markets for homogeneous products. Studies of online travel agent offerings have found that ticket prices vary by as much as $20 \%$ across travel agents even after controlling for observable product heterogeneity (Clemons, Hann \& Hitt 1998). Bailey (1998) found that price dispersion for books, CDs and software is no smaller online than in conventional markets. A more recent study by Brynjolfsson and Smith (2000) examined prices for books and CDs sold through Internet and conventional channels in 1998 and 1999. They find that prices are 9-16\% lower on the Internet than in conventional outlets - even after accounting for costs from shipping and handling, delivery, and local sales taxes. They found that prices for identical books and CDs at different online retailers differ by as much as $50 \%$, and on average by $25 \%$ for CDs. Consumer behavior online is also expected to be different from conventional markets. 
Whether the Internet will lead us to more efficient markets is a subject for further empirical tests as it is still a relatively new phenomenon (Bakos 1998). Our study goes beyond the previous studies to investigate the following -

(a) First, we look at two categories of the same product - mainstream products that are expected to have current mass-market appeal, and niche products that are expected to appeal to narrower segments. We empirically explore differences in market characteristics for product categories, and derive insights about Internet retailers' pricing strategy. This is important because we hypothesize that different marketing channels may require distinct strategies depending on product attributes.

(b) Second, we compared prices in two distinct time periods to enable a longitudinal analysis to be done. Earlier studies such as Brynjolfsson and Smith (2000) reported only cross-sectional analyses. However, there is speculation that the early Internet companies were operating with evolving business models, This may have led to initial lower prices in a bid to attract "eyeballs" rather than profits. The results from the longitudinal analysis will provide us with a better understanding of retailer pricing for different product categories over a period of time.

(c) Lastly, but most importantly, while earlier studies have focused on consumer-side analysis of electronic markets, we explicitly consider both the consumer and seller side impact of IT. A recent study by Grover and Ramanlal (1999) suggests that sellers can employ information-based strategies enabled by IT to improve their margins, impeding market efficiency. By customizing products, discriminating consumer demands and locking in customers using proprietary networks, the seller may extract more of the consumer surplus than they would at the competitive equilibrium. Accordingly, we discuss both the supply and demand sides of the nascent markets.

\section{Research Method}

We believe that important issues related to the structure of Internet-based electronic markets vis-à-vis their physical counterparts still remain unsettled. Understanding and resolving issues should begin from the basics. For this reason, we have investigated a mass-produced commodity-like product in this study. The choice of music compact disks as a product in our study is driven by their commodity-like nature, their popularity in the electronic marketplace and our intention to repeat the previous studies based on a different framework.

We first listed music stores that have the largest collection of CDs on the Internet by using Internet search engines. Stores that carry special types of music (e.g. Latin Music, Foreign Music, etc.) were excluded, and only those that provided product and price information through a searching mechanism were selected. As a result, we identified nine on-line stores. Brick-and-mortar retailers were selected based on size. Limiting ourselves to a single market area, we 
identified five nationally-recognized CD stores in a major US metropolitan area (see Appendix A for the list of shops included in this study).

Since we expected that the pricing strategy for mainstream high volume products could be different for specialized niche products, we collected prices for two kinds of albums - current-hits and old-hits. This was done because temporal currency is an important attribute that impacts pricing and marketing decisions because it drives distinct patterns of customer behavior. Prices were collected for one week's (current-hits) Billboard chart and for the same period ten years ago (old-hits) of the Billboard chart. As a result, we have 21 current-hit albums and 22 old-hit albums. Approximately one year after the first data collection, $\mathrm{CD}$ prices were collected for the same albums from the same brick-and-mortar and on-line stores. Overall, a total of $905 \mathrm{CD}$ prices, 572 from the Internet and 333 from brick-and-mortar stores were collected over 43 different albums.

\section{Results}

\section{Price Dispersion}

First, we investigated the issue of price dispersion in electronic markets. Although Hypothesis 1 suggests a comparison between online and physical markets, we first wanted to test whether there were systematic price differences among online retailers since price convergence is expected with zero search costs. An OLS regression model that relates the prices of albums to the identity of nine different Internet retailers was used. The independent variables in the model were coded as dummy variables that have value 1 for the corresponding Internet retailer and 0 otherwise. The dependent variable was the percentage deviation of a specific album price ( $i$-th album) at one retailer ( $j$-th shop) from the average price of that album across the Internet retailers (PDij). While we could use price differences instead of the percentage of deviation, the percentage price dispersion led to a normal distribution of the errors, allowing for homoscedasticity assumptions to be met.

The dependent variable is,

$P D_{i 1}=\underline{\text { (Price of } i-\text { th album at the } j \text {-h th retailer - Average Price of } i-\text { th Alhum across different retailers) }}$ Average Price of i-th Album across different retailers

Then

The model becomes

$P_{1 i}=\beta_{1}{ }^{*} P_{1}+\beta_{2}{ }^{*} P_{2}+\beta_{3}{ }^{*} P_{3}+\beta_{4}{ }^{*} P_{4}+\beta_{5}{ }^{*} P_{5}+\beta_{6}{ }^{*} P_{6}+\beta_{7}{ }^{*} P_{7}+\beta_{8}{ }^{*} P_{8}+\beta_{9}{ }^{*} P_{4}+e_{i j}$

For $\quad \mathrm{i}=1$ to 43 (albums), and

$\mathrm{j}=1$ to 9 (Internet Retailers) 
where $P_{j}$ is dummy variable with

$P_{j}=1$ if prices in $P D_{i j}$ are for the $j$-th retailer

$=0$ otherwise.

Since the average price is reflected in the model, the intercept term was excluded from the model. The b coefficients, then, indicated the average percentage deviation in price of albums between the $\mathrm{i}$-th Internet shop and the overall average Internet price. Table 1 shows the results of the regression analysis.

Table 1

Modeling Price Differences across Internet Retailers

\begin{tabular}{|c|c|c|c|c|c|c|}
\hline & \multicolumn{3}{|c|}{ Data Collected in Feb. 1999} & \multicolumn{3}{|c|}{ The same data after one year(January 2000) } \\
\hline & $\begin{array}{l}\text { For all } \\
\text { Albums }\end{array}$ & $\begin{array}{l}\text { For } \\
\text { Current-hit } \\
\text { Albums }\end{array}$ & $\begin{array}{l}\text { For Old-hit } \\
\text { Albums }\end{array}$ & $\begin{array}{l}\text { For all } \\
\text { Albums }\end{array}$ & $\begin{array}{l}\text { For } \\
\text { (used to be) } \\
\text { Current-hit } \\
\text { Albums }\end{array}$ & $\begin{array}{l}\text { For } \\
\text { (used to be) } \\
\text { Old-hit } \\
\text { Albums }\end{array}$ \\
\hline$\beta_{1}$ & $\begin{array}{l}-0.021^{*} \\
(0.011)\end{array}$ & $\begin{array}{l}0.033 * * \\
(0.012)\end{array}$ & $\begin{array}{l}-0.06 * * * \\
(0.013)\end{array}$ & $\begin{array}{l}0.0002 \\
(0.009)\end{array}$ & $\begin{array}{l}0.197^{*} \\
(0.011)\end{array}$ & $\begin{array}{l}-0.015 \\
(0.009)\end{array}$ \\
\hline$\beta_{2}$ & $\begin{array}{l}-0.057 * * * \\
(0.014) \\
\end{array}$ & $\begin{array}{l}-0.0063 \\
(0.17) \\
\end{array}$ & $\begin{array}{l}-0.084^{* * *} \\
(0.014) \\
\end{array}$ & $\begin{array}{l}-0.113 * * * \\
(0.008) \\
\end{array}$ & $\begin{array}{l}-0.092 * * * \\
(0.010) \\
\end{array}$ & $\begin{array}{l}-0.131 * * * \\
(0.009) \\
\end{array}$ \\
\hline$\beta_{3}$ & $\begin{array}{l}-0.0018 \\
(0.013)\end{array}$ & $\begin{array}{l}0.032 * \\
(0.017)\end{array}$ & $\begin{array}{l}-0.018 \\
(0.014)\end{array}$ & N/A & $\mathrm{N} / \mathrm{A}$ & $\mathrm{N} / \mathrm{A}$ \\
\hline$\beta_{4}$ & $\begin{array}{l}0.102 * * * \\
(0.011) \\
\end{array}$ & $\begin{array}{l}0.044 * * * \\
(0.011) \\
\end{array}$ & $\begin{array}{l}0.171 * * * \\
(0.014) \\
\end{array}$ & $\begin{array}{l}-0.0004 \\
(0.008) \\
\end{array}$ & $\begin{array}{l}0.033 * * * \\
(0.010)\end{array}$ & $\begin{array}{l}-0.038 * * * \\
(0.009) \\
\end{array}$ \\
\hline$\beta_{5}$ & $\begin{array}{l}-0.021 \\
(0.014)\end{array}$ & $\begin{array}{l}-0.036^{* *} \\
(0.011)\end{array}$ & $\begin{array}{l}0.049^{*} \\
(0.030)\end{array}$ & $\begin{array}{l}0.053^{* * *} * \\
(0.008)\end{array}$ & $\begin{array}{l}0.017 * \\
(0.010)\end{array}$ & $\begin{array}{l}0.092 * * * \\
(0.009)\end{array}$ \\
\hline$\beta_{b}$ & $\begin{array}{l}-0.037 * * \\
(0.017)\end{array}$ & $\begin{array}{l}-0.024 \\
(0.016)\end{array}$ & $\begin{array}{l}-0.057 * * \\
(0.024)\end{array}$ & $\mathrm{N} / \mathrm{A}$ & $\mathrm{N} / \mathrm{A}$ & $\mathrm{N} / \mathrm{A}$ \\
\hline$\beta_{7}$ & $\begin{array}{l}-0.0014 \\
(0.011) \\
\end{array}$ & $\begin{array}{l}0.047 * * * \\
(0.011) \\
\end{array}$ & $\begin{array}{l}-0.048^{* * *} \\
(0.013)\end{array}$ & $\begin{array}{l}0.017^{*} \\
(0.009) \\
\end{array}$ & $\begin{array}{l}0.0376^{* * *} \\
(0.011)\end{array}$ & $\begin{array}{l}0.0032 \\
(0.009) \\
\end{array}$ \\
\hline$\beta_{8}$ & $\begin{array}{l}0.039 * * *-1 \\
(0.011)\end{array}$ & $\begin{array}{l}0.012 \\
(0.011) \\
\end{array}$ & $\begin{array}{l}0.092 * * * \\
(0.013)\end{array}$ & $\begin{array}{l}0.0073 \\
(0.009) \\
\end{array}$ & $\begin{array}{l}0.00358 \\
(0.010) \\
\end{array}$ & $\begin{array}{l}0.012 \\
(0.010) \\
\end{array}$ \\
\hline$\beta_{y}$ & $\begin{array}{l}-0.044 * * * \\
(0.011)\end{array}$ & $\begin{array}{l}-0.067^{* * * *} \\
(0.011)\end{array}$ & $\begin{array}{l}-0.021^{*} \\
(0.013)\end{array}$ & $\begin{array}{l}0.035 * * * \\
(0.008)\end{array}$ & $\begin{array}{l}-0.025^{* *} \\
(0.010)\end{array}$ & $\begin{array}{l}0.095^{* * *} \\
(0.009)\end{array}$ \\
\hline $\mathrm{N}$ & 296 & 147 & 149 & 276 & 131 & 145 \\
\hline $\mathrm{F}$ & $15.431 * * *$ & $10.785 * * *$ & $30.326 * * *$ & $34.921 * * *$ & $17.067 * * *$ & $61.93 * * *$ \\
\hline $\mathrm{R}^{2}$ & $32.6 \%$ & $41.3 \%$ & $66.1 \%$ & $47.6 \%$ & $49.1 \%$ & $75.9 \%$ \\
\hline
\end{tabular}


Based on the results shown in Table 1 (column 2), we reject the hypothesis that there is no price dispersion in the Internet market (Overall model is significant; $F_{9.287}=15.431, p<0.001$ ). The deviation of the price from the average album price ranges from $-5.7 \%$ to $10.2 \%$.

Next we investigate whether the price dispersion is the same for the different product categories - old hits albums and the current hits albums. The regression models were run separately for each group and analyzed. The results (the third and the fourth column of Table 1) indicate that the price dispersion exists regardless of the product type. The F-values are 10.785 and 30.326 for the current and old albums respectively, rejecting the equal price hypothesis at the 99\% level of confidence in both cases. The price dispersion was higher for the old albums: The price dispersion ranges from $-8.4 \%$ to $17 \%$, indicating a price dispersion range of over $25 \%$ for the old album while it was relatively lower for the current albums, ranging from $-6.7 \%$ to $4.7 \%$.

An important issue in examining price dispersion is to overlay that with market share information. If one retailer is significantly higher in price and likely to be pricing itself out of the market, it may not be appropriate to include it in the analysis of market price dispersion. Since the market share data were not available for all Internet retailers (especially small retailers which have not been publicly listed), we decided to compare prices for the two leading Internet music stores (stores 5 and 9) that combined account for more than $80 \%$ of current Internet music CD sales.

In order to test whether they have similar pricing we propose the null hypothesis, $H 0: \beta 5=\beta 9$, and test it using $F$-value changes in the full and reduced model. Since the multiple $\mathrm{R}^{2}$ for the reduced equations yield 0.391 and 0.644 for old and current albums respectively, the F-tests applying the equation results are $F_{(1,137)}$ $=5.31$ and $F_{(1,139)}=6.9$, respectively. Both are significant at the $95 \%$ level. Therefore, we reject the hypothesis that the two leading Internet music CD retailers have the same price.

How do we compare the price dispersion in brick-and-mortar and Internet markets? Although an F-test can be used for testing for equal variance from two samples, the percentage of price difference between the highest-priced and lowest-priced stores for each album is used because each different album should be treated independently. Since the number of stores in the brick-and-mortar is only 5 compared with 9 in the Internet, caution is necessary in interpreting the result; it is likely that the dispersion will be higher for the Internet just because of the larger number of retailers. Among the twenty-one current-hit albums, the average percentage price difference is $18 \%$, which was very similar to $19 \%$ for the brick-and-mortar markets. For old-hit albums, the price dispersion among Internet stores is much higher than among brick-and-mortar stores. For twentytwo old-hit albums, the average percentage price difference was $31 \%$ in the Internet market ranging from $8 \%$ to $51 \%$, while it was only $11 \%$ in the brickand-mortar market. 
Figure 1

Average Price Dispersion for Brick-and-Mortar and Internet Retailers

Average Price Dispersion

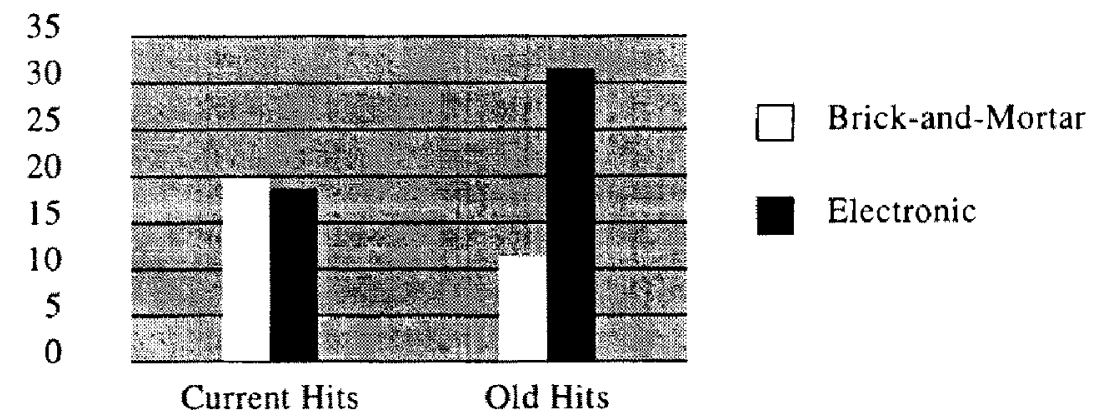

Figure 1 provides evidence of the dispersion independent of the regression model. The regression model looks at systematic retailer effects and would miss dispersion effects that were not consistent for a retailer. A retailer, for example, may discount some titles and inflate prices for others. The average price dispersion provides, therefore, a coarse summary measure that supports the findings of the systematic effects model.

To summarize, $\mathrm{H} 1$ was not supported as price differences among online retailers were persistent, and there is no evidence that price dispersion is lower in the online market. Besides, the price dispersion is even bigger in the Internet market for old-hit albums. Hla is supported as two different product types show very different patterns of price dispersion between two markets.

\section{Price Difference Between Brick-and-Mortar and Internet Retailers}

Next we investigate the difference in price levels between the two markets $(\mathrm{H} 2)$. Comparing prices requires the adjustment of prices; a shipping and handling $(\mathrm{S} \& \mathrm{H})$ cost for the Internet market and a tax charge for the physical market. Currently Internet retailers charge $\$ 2.95$ to $\$ 4.95$ for a single CD or usually $\$ 2.99+\$ 0.96$ per item, and each brick-and-mortar shop has a different tax rate depending on the state. Taxes on Internet sales are based on whether the buyer resides in the state where the retailer has a nexus. We adjusted the shipping and handling cost for each on-line shop based on three CD purchases following Brynjolfsson and Smith (2000) and a uniform $6 \%$ tax rate was added for the brick-and-mortar market. Later, a sensitivity analysis was conducted for various ranges of tax rates (e.g. $4 \%$ to $8 \%$ ) and various $\mathrm{S} \& \mathrm{H}$ costs (e.g. buying one $\mathrm{CD}$ to buying $3 \mathrm{CDs}$ ). We will report later but it is worth noting that the $C D$ prices are very sensitive to $S \& H$ cost. For example, we have to add on $\$ 3.95$ for a single CD purchase, but it comes to $\$ 1.96$ per album for a three $\mathrm{CD}$ purchase on Amazon.com, more than the $12 \%$ price difference for an average $\mathrm{CD}$. As a result, the direct price comparison between the physical and Internet 
markets are very sensitive to assumptions on how many CDs consumers purchase at one time.

A non-parametric test, the Wilcoxon signed rank test was selected for the comparison since the data are differences in price from two related samples (brick-and-mortar and Internet stores), where each album may have a different price depending on retailer strategy. We could have used paired t-tests instead, but the small sample size and the assumptions of normality were a concern. While the sign test considers only the direction of signs, the Wilcoxon signed rank test is more powerful as it considers not only the signs but the magnitude of the signs (Siegel \& Castellan 1988). So, it can take into consideration price differences that may result from a chance error. Prices are compared for both average differences and the cheapest available prices in the two markets. After the differences of prices (i.e. Brick-and-Mortar price - Internet store price) are calculated for each album, its sign direction along with absolute values of differences was ranked for the Wilcoxon signed rank test. Then, $\mathrm{T}^{+}$, the positive ranks are summed.

For the large sample size (i.e. typically over 15 ), $\mathrm{T}^{+}$, is approximately normally distributed with

Mean $=n(n+1) / 4$,

Variance $=n(n+1)(2 n+1) / 24$,

Therefore,

$$
z=\frac{T^{+}-n(n+1) / 4}{\sqrt{n(n+1)(2 n+1) / 24}} \sim N(0,1)
$$

Table 2 shows the result of Wilcoxon ranked sign test for price comparison between the brick-and-mortar market and on-line stores across old and currenthit albums.

Table 2 shows that the Internet market of old-hit albums is cheaper for 19 out of 19 albums in terms of both average and cheapest price available comparison, yielding $z$-value -3.8 and -3.85 respectively $(\mathrm{p}<0.01$, based on $6 \%$ tax and 3 CDs purchase).

The price comparison for the current-hit albums showed similar but slightly different results. A comparison based on both average and cheapest available prices also shows the similar result with $z=-3.49$ and -3.17 , respectively $(p<0.01)$, suggesting that physical markets are more expensive for current-hit albums, too. The result, however, was very sensitive to $S \& H$ cost charges (it was insensitive to the tax rate from $4 \%$ to $8 \%$ ). When we assumed one $C D$ purchase - in this case adjusted $\mathrm{CD}$ prices for the Internet market became more expensive - current-hit albums are cheaper in the physical market while old-hit albums are still cheaper in the Internet market (i.e. the result for the current-hit albums reversed from the case when we 
assumed three purchases per visit). A simple mean difference between two markets confirmed that the price differences for the current-album was only $\$ 0.67$, (it was $\$ 1.83$ for the old-hit albums) when three CD purchases are assumed.

Table 2

The z-values of the Wilcoxon signed rank test (Price Comparison for Internet and Brick-and-Mortar Retailers)

\begin{tabular}{|c|c|c|}
\hline & \multicolumn{2}{|c|}{ Data Collected in Feb. 1999} \\
\hline & Average Price & Cheapest Price \\
\hline Current-hit Albums & $-3.49 * *$ & $-3.17 * *$ \\
\hline Old-hit Albums & $-3.8 * *$ & $-3.85 * *$ \\
\hline All Albums & $-5.3 * *$ & $-5.2^{*}$ \\
\hline
\end{tabular}

We could not compare the prices of the two markets controlling for market share information since exact market share information was difficult to acquire. But, in order to explore the impact of market share, we did the same analysis with the two leading online shops that combined account for more than $80 \%$ of the market share. The results indicated that, similar to the previous analysis, current-hit albums do not have any difference in price $(z=-0.47)$ and the old-hit albums are cheaper in the Internet market $(z=-3.67, p<0.01)$. Therefore, combing two analyses, we conclude that there is not much price difference between physical and on-line shops for current-hit albums, but prices for old-hit albums are cheaper in the Internet market. So, $\mathrm{H} 2$ is supported as, on average, prices are cheaper in the Internet market. H 2a is also supported as the two product types show different patterns of price differences.

\section{Price Changes Over Time}

One year after the first data collection, we again collected price data for the same albums. Since one of the Internet retailer web-sites was being remodeled and another one was extinct, analyses are conducted based on seven Internet retailers.

The regression analysis indicates that price dispersion among Internet stores remained high (see the fifth, sixth and seventh columns of Table 1). We can still reject the hypothesis that the prices are equal across the Internet market $\left(\mathrm{F}_{7,276}=\right.$ $34.92, \mathrm{p}<0.01$ ). The deviation of prices from the average album price ranges from $-11 \%$ to $5 \%$. Furthermore, price dispersion seems to increase as the variance explained increased for all current-hit $\left(R^{2}\right.$ increases to 0.49 from 0.41$)$ and old-hit albums ( $R^{2}$ increases to 0.76 from 0.66 ) despite the fact that the number of retailers included in the model decreased. 
Price comparison between brick-and-mortar and Internet retailers show results that are similar to the earlier period. It shows that brick-and-mortar prices are dominantly higher than prices from Internet retailers in old-hit albums, and comparable for the current-hit albums. However, it is of interest to observe how prices have changed in the two different marketplaces. The following crosstable (Table 3 ) shows the price difference (i.e. Old price - Current price) by the market and by the product. The negative number represents that the stores increased prices for the albums.

Table 3

Changes in Prices over Time

\begin{tabular}{|c|c|c|c|c|c|c|c|}
\hline \multirow[b]{2}{*}{$\begin{array}{l}\text { Change in } \\
\text { prices over } \\
1 \text { year }\end{array}$} & \multicolumn{3}{|c|}{ For Current-hits } & \multicolumn{3}{|c|}{ For Old-hits } & \multirow[t]{2}{*}{ Total } \\
\hline & $\begin{array}{l}\text { Price } \\
\text { Change }\end{array}$ & $\begin{array}{l}\% \text { of } \\
\text { albums } \\
\text { with } \\
\text { small } \\
(<10 \%) \\
\text { price } \\
\text { change }\end{array}$ & $\begin{array}{l}\% \text { of } \\
\text { albums } \\
\text { price } \\
\text { unchanged }\end{array}$ & $\begin{array}{l}\text { Price } \\
\text { Change }\end{array}$ & $\begin{array}{l}\% \text { of } \\
\text { albums } \\
\text { with } \\
\text { small } \\
(<10 \%) \\
\text { price } \\
\text { change }\end{array}$ & $\begin{array}{l}\% \text { of } \\
\text { albums } \\
\text { price } \\
\text { unchanged }\end{array}$ & \\
\hline $\begin{array}{l}\text { Brick-and- } \\
\text { Mortar }\end{array}$ & \begin{tabular}{|l|}
$-0.18^{* * * *}$ \\
$(0.12)$ \\
$(81)$ \\
\end{tabular} & $4.9 \%$ & $16 \%$ & $\begin{array}{l}-0.004 \\
(0.11) \\
(47)\end{array}$ & $6.4 \%$ & $85 \%$ & $\begin{array}{l}-0.12^{* *} \\
(0.14) \\
(125)\end{array}$ \\
\hline Internet & $\begin{array}{l}-0.04^{* * *} \\
(0.009) \\
(115) \\
\end{array}$ & $36 \%$ & $19 \%$ & $\begin{array}{l}0.07^{* *} \\
(0.16) \\
(118) \\
\end{array}$ & $23 \%$ & $5.1 \%$ & $\begin{array}{l}0.02^{* * *} \\
(0.14) \\
(233) \\
\end{array}$ \\
\hline Total & $\begin{array}{l}-0.10^{* * * *} \\
(0.12) \\
(196)\end{array}$ & & & $\begin{array}{l}0.048^{* * *} \\
(0.15) \\
(165)\end{array}$ & & & $\begin{array}{l}-0.03 * * \\
(0.154) \\
(361)\end{array}$ \\
\hline
\end{tabular}

Standard deviation in the first parenthesis; number of albums in the second parenthesis; ${ }^{* * *} p<0.01,{ }^{*} p<.05,{ }^{*} p<0.1$, testing $H_{0}$ : no price difference

The numbers in Table 3 show that brick-and-mortar stores have a clearly distinct pricing strategy for the two different types of albums. They sharply increased the prices of current-hit albums of one year ago; price increases average $18 \%$. However, they left the prices of old-hit albums unchanged (more than $85 \%$ of old-hit albums have not had price changes). The on-line stores also increased prices for their current-hit albums, but the increase has a wide dispersion depending on albums, and the increase is much smaller, only $4 \%$ on average. For the old-hit albums, the on-line stores decreased the price slightly, but again show a wide dispersion within the same product category. The online stores exhibit a finer granularity of change: the change in prices was within $10 \%$ of the earlier price for $36 \%$ of current-hit albums and $23 \%$ of old-hit albums. The corresponding proportion was $5 \%$ and $6 \%$ respectively for 
brick-and-mortar retailers. The analysis indicated that online shops executed much finer granularity of changes compared with physical markets. Since the data were collected at only two time periods, and we can observe the price change once, we cannot conclude that the rate of change is greater in electronic markets. But the fact that most physical stores do not change their old-hit album prices indicates that $\mathrm{H} 3$ is partially supported. $\mathrm{H} 3 \mathrm{a}$ is supported as both markets showed very distinct pricing strategies for old-hit and current-hit albums.

\section{Discussion}

Our results suggest that on-line retailers have a very different pricing strategy from the conventional retailers. Physical shops offer significant price breaks on the more popular products and increase prices once the products do not have sustained mainstream market appeal. They increased prices averaging $18 \%$ compared to a $4 \%$ price increase for the on-line stores. For more niche products, the brick-and-mortar did not change prices but on-line stores decreased prices by about $7 \%$. On-line stores, on the other hand, have much more dynamic pricing strategies. While conventional stores leave their prices for old-hit albums unchanged (more than $85 \%$ of their album prices were unchanged), on-line stores changed prices of $95 \%$ of their old-hit albums. Additionally, Internet retailers show much finer price adjustments, indicating that they employ a relatively more dynamic pricing strategy. Overall, the larger increase in brick-and-mortar store prices for current albums after their popularity has gone combined with the decrease in prices for the Internet stores explained why old-hit albums are more expensive in the physical shops, and Internet prices become dominantly cheaper.

Our results, combined with previous studies of the music CD market, provide a number of important insights. Since our study is based on one type of product and regional physical markets, generalization of the results beyond the $\mathrm{CD}$ market might be difficult. The study does provide a basis for building our knowledge in the area, and should be augmented with different research designs and theoretical grounding.

First, unlike previous studies that empirically demonstrated price dispersion and cheaper prices in the Internet market, our study shows how sellers in the new Internet market may react to the trend of "near-zero" search costs. Grover and Ramanlal (1999) argue that while we usually possess a congenital view that IT will benefit the buyer by decreasing the price, the supplier also will exert alternative strategies to extract consumer surplus, making the trend more interacting and complex. Our results show that Internet retailers are able to exert finer-grained control over prices based on their lower menu cost. They are also able to experiment with new pricing strategies as opposed to the conventional shops that only change prices once the $C D$ moves into less popular vintage, and they tend to adjust prices by a larger amount.

Second, we show that the price structures and dynamics for the two different product categories (i.e. popular products vs. niche products) are very distinct, 
and that the distinction strongly reflects the deliberate pricing strategies of retailers. In comparing conventional brick-and-mortar and on-line stores, these two categories are different in terms of both price differences and price dispersion. Larger price dispersion is observed for old-hit albums, and price differences of current-hit albums between the physical and the Internet markets are much smaller than those of old-hit albums. Understanding these results requires us to think of the electronic markets as a totally new market with different cost structures and possibly a different consumer basis. Studies have found that differences in cost structure such as inventory cost and selling cost result in different pricing strategies. Eppen and Liebermann (1984), for instance, show that sellers with higher inventory costs will offer periodic price deals as a mechanism for minimizing inventory holding costs. Then, the higher inventory cost of the brick-and-mortar stores might lead to price breaks for the current-hit albums as was observed in the study. Another reason for price breaks may be sellers adopting more "inducing strategies." One way in which price breaks for popular products work is that sellers induce customers with notable products and induce them to purchase other products. The assumption here is that customers commit the resources to purchase a product (i.e. going to the shop) and that by purchasing other products they will save on the average purchasing cost. Then, "inducing customers" by lowering the prices for the most popular products may be more effective in the brick-and-mortar shops than in the electronic market. It is expected, then, that sellers tend to "sale" their prices in brick-andmortar markets (in response to seasonal and other factors) to a greater extent than electronic markets. Our results also show that the brick-and-mortar markets have more price breaks for popular CDs. These price breaks make the brick-andmortar markets comparable in Internet market prices for the currently popular products. The strategy further entails increasing the prices once the "popularity" declines.

Finally, differences in the two product categories suggest that the dynamic nature of pricing strategies needs to be understood and captured in the new models of electronic commerce. Current developments in the electronic market have witnessed new purchasing methods, settlement method and marketing technologies in the Internet market, and these changes lead to different consumer segmentation, pricing strategies and consumer behaviors (Rayport \& Jaworski 2000). At the retailer end, segmentation may be based on information-use profiling of consumers, for example, to determine their price sensitivity and employ discriminatory pricing. This information processing makes narrower segmentation strategies viable and also enables finer-grained price changes. At the consumer end there may be natural segmentation due to differences in price sensitivity, familiarity/awareness of search tools, product/service preferences and risk profiles. From a consumer behavior perspective, a study by Clemons, Hann and Hitt (1998) argues that even a commodity-like product can have differentiation. On-line $\mathrm{CD}$ stores can differentiate the product through 
shop credibility, promised delivery time, an easier searching mechanism, a refund guarantee, suggested products and product evaluation. Another study by Bailey, Yao and Faraj (1999) shows that price dispersion is partly explained by firm strategy. Further, evaluating products online may lead to "missing information" regarding the characteristics of the product (Degeratu, Rangas wamy \& Wu 1998) and may lead consumers to rely more heavily on other signals of quality, such as brand. These new observations and opportunities all suggest that it is not that the Internet market simply provides the cheaper prices, therefore the more benefit to the consumers due to search cost reduction. We, then, need to understand this new market and the new marketing and pricing strategy that suit this new market structure. By empirically investigating pricing in brick-and-mortar and Internet markets, and comparing price differences for two different types of products, this exploratory study showed that price dispersions and prices differences depend on product structures, and suggested that the structural differences between two markets might contribute to price dispersion and higher than expected average prices for Internet retailers.

\section{Conclusion}

Consistent with previous studies, our study confirms that price variance exists on the Internet even for the simplest commodity-type products. Direct price comparison also confirmed the previous results that prices in the Internet are generally cheaper than in the physical market (Brynjolfsson \& Smith 2000). When we look at product categories, "popular" and "niche," however, we find differences in prices and price dispersion patterns. Lower price dispersion was reported for the current-hit albums: There are consistent $15 \%$ to $20 \%$ price differences for the current-hit and $25 \%$ to $35 \%$ differences for the old hits. Direct price comparison also revealed that $C D$ prices for current-hit albums in the physical markets are comparable to prices in the Internet market and the old-hit albums are consistently cheaper in the Internet market.

The longitudinal data of our study suggest that the price variance on the Internet is not getting smaller, and may actually be increasing. For both old and current hit albums, the variances explained due to price dispersion increased. Since the first data collection, we have witnessed an enormous increase in ecommerce volumes and emergence of a number of price comparison sites (e.g. mysimon.com, cnet.com, pricescan.com, bottomdollar.com), driving searching costs down. The results, however, indicate that the price dispersion is persistent. Besides, the two leading on-line shops that account for more than $80 \%$ of the total market share are not the dominant price leaders. This study paves the way for a better understanding and crafting of pricing strategies by illuminating variation in prices over time and across product categories with different customer bases and cost structures. 


\section{References}

Bailey, J. (1998). Intermediation and electronic markets: Aggregation and pricing in Internet commerce, Ph.D. Dissertation. Technology, Management and Policy, Massachusetts Institute of Technology, Cambridge, MA.

Bailey, J., Yao, Y. \& Faraj, S. (1999). Price dispersion among Internet retailers. Workshop on Information Systems and Economics.

Bakos, Y. (1991). A strategic analysis of electronic marketplaces. MIS Quarterly. 15 (3), September, 295-310.

Bakos, Y. (1997). Reducing buyer search costs: Implications for electronic marketplaces. Management Science, 43 (12), December, 1676-1692.

Bakos, Y. (1998). The emerging role of electronic marketplaces on the Internet. Communications of ACM. 41 (8), 35-42.

Benjamin, R. \& Wigand, R. (1995). Electronic markets and virtual value chains on the information superhighway. Sloan Management Review, Winter, 62-72.

Brynjolfsson, E. \& Smith, M. D. (2000). Frictionless commerce? A comparison of Internet and conventional retailers. Management Science, 46 (4), 563-585.

Clemons, E., Hann, I. \& Hitt, L. (1998). The nature of competition in electronic markets: An empirical investigation of online travel agent offerings. Department of Operations and Information Management Working Paper, The Wharton School.

Degeratu, A., Rangaswamy, A., \& Wu, J. (1998). Consumer choice behavior in online and regular stores: The effects of brand name, price, and other search attributes. Presented at Marketing Science and the Internet, INFORM College on Marketing Mini-Conference.Cambridge, MA. 6-8 March.

Eppen, G. D. \& Liebermann, Y. (1984). Why do retailers deal? An inventory explanation. Journal of Business, 57, October, 519-530.

Grover, V. \& Ramanlal, P. (1999). Six myths of information and markets: Information technology networks, electronic commerce, and the battle for consumer surplus. MIS Quarterly, 23 (4), 455-485.

Milgrom, P. \& Roberts, J. (1982). Limit pricing and entry under incomplete information. Econometrica, 50, 443-460.

Rayport, J. \& Jaworski, B. J. (2000). e-Commerce. New York: McGraw-Hill/Irwin.

Salop, S. (1979). Monopolistic competition with outside goods. Bell Journal of Economics. $10,141-156$. 
Sheshinski, E., \& Weiss, Y. (Eds.) (1993). Optimal pricing, inflation, and the cost of price adjustment. Cambridge, MA: MIT Press.

Siegel, S., \& Castellan, Jr., J. (1998). Non-parametric statistics for the behavioral sciences. New York: McGraw-Hill. Inc.

Smith, M. D., Bailey, J., \& Brynjolfsson, E. (1999). Understanding digital markets: Review and assessment. MIT Working Paper, Massachusetts Institute of Technology, Cambridge, MA.

\section{Appendix A \\ List of Stores Included in This Study}

\section{Internet Stores}

AbbyRoad: www.abbyroad.com

All Direct: st5.yahoo.com/cgi-bin/ addback?acct=adirect

Amazon: www.amazon.com

Borders: www.borders.com

CD Connection: www.cdconnection.com

CDNow: www.cdnow.com

CD world: www.cdworld.com

Spree: www.spree.com

Tower Records: www.towerrecords.com

\section{Brick-and-Mortar Stores}

Barnes \& Noble

Borders

Sam Goody

Tower Records

Virgin

Zoonky Lee is Assistanat Professor of Information Systems at the University of Nebraska - Lincoln. He holds a Ph.D. degree from the University of Southern California. His current research interests include Designing IT Infrastructures for Organizational Learning and E-Business. He has published in Information and Management, Journal of Organizational Computing and Electronic Commerce, Journal of Information Technology and Electronic Markets.

Sanjay Gosain is Assistant Professor of Information Systems at the Robert $\mathrm{H}$. Smith School of Business at the University of Maryland. His research is focused on the design and analysis of information systems, particularly to support interorganizational coordination as well as issues related to electtonic business. 
